\title{
Contribution to the Physico-Mechanical Characterization of Career Sands in the Western Region in Cameroon
}

\author{
Nie Noumsi Thierry Constant \\ (Ing;MSc) \\ Fotso Victor University Institute of Technology, \\ Civil Engineering Department, , Research Unity of Mechanical and Modulation of Physical Systems (UR2MSP), \\ Research Unity of Industrial Systems and Engineering Environment (URISIE), \\ University of Dschang Cameroon,
}

\author{
Kamdjo Gregoire \\ (Associate Professor) \\ Fotso Victor University Institute of Technology, \\ Civil Engineering Department, , \\ Research Unity of Industrial Systems and Engineering \\ Environment (URISIE), \\ University of Dschang Cameroon,
}

\author{
Ngapgue Francois \\ (Associate Professor) \\ Fotso Victor University Institute of Technology, \\ Civil Engineering Department, \\ Research Unity of Industrial Systems and Engineering \\ Environment (URISIE), \\ University of Dschang Cameroon,
}

\begin{abstract}
The objective of our study is the physico-mechanical characterization of quarry sands in the West Cameroon region with a view to their rational use in civil engineering works. This work was done in two ways:

- In the field we took samples

- In the laboratory we did some tests.

Laboratory studies focused on:

$\checkmark$ Physical characterization which is an intrinsic property: water content, specific weights, density, sand equivalent, dry particle size analysis, sedimentation, granularity.

$\checkmark \quad$ Mechanical characterization: Proctor test, CBR test and concrete formulation.

The study concludes that representative samples of the sand analyzed have physical and mechanical properties such that: the specific gravity is $2.46 \mathrm{~g} / \mathrm{cm} 3$, the apparent density is 1.9 g / cm3, the sand equivalent is $67.2 \%$, The modulus of fineness (Mf) is 3.3, The Immediate CBR is 10.37, the Normal Proctor test shows a maximum dry density of $1.68 \mathrm{~g} / \mathrm{cm} 3$ for an optimal Moisture content of $\mathbf{1 2 . 1 8} \%$, the Modified Proctor test also stands out a maximum dry density of $1.74 \mathrm{~g} / \mathrm{cm} 3$ for an optimal Moisture content of 14.8 and the compressive strength of Concrete at 28 days is $25.08 \mathrm{MPa}$.
\end{abstract}

Key words: Characterization; Physico-Mechanical; Sand; Geotechnic; Career.

\section{1- INTRODUCTION}

Aggregates are inert materials derived from rock erosion or grinding, which agglomerated by a binder constitute the skeleton of concretes and mortars. Aggregates can be rolled and deposited by erosion agents (wind, volcano, and water) or crushed (angular and quarried). Aggregates are of great importance because they are at the base of mortars, hydraulic concretes, as well as hydrocarbon concretes (bituminous concretes). They also serve as ballast (crushed granulate of size between 25 and $50 \mathrm{~mm}$ ) without fines used in particular in the structural structures of the civil engineering structures. Their use is more and more important and in great mass. The aggregates are said:

$\checkmark$ Natural when they come from loose or massive rocks and which undergo no treatment other than mechanics. These aggregates come from quarries, gravel pits, sand pits and borrow pits.

$\checkmark$ Artificial when they come from the transformation of both thermal and mechanical rocks. Most of them are only used for lightweight insulating and low-resistance filling concrete.

A lot of work has been done (huge work has been done on the use of sand) in the manufacture of concrete and mortars. Granites are famous rocks for their hardness and resistance contributing to the construction of buildings. However, none analysis was conducted on the sands of Career of the MiFi in the Western Region Cameroon. In addition granites and its alteration products have been carefully studied by several researchers such as : Fetgo B. [28] (2002) who carried out the geotechnical characterization of alteration products sector of Bafou by limiting itself to the intrinsic parameters of the material. Kouayep Lawou S. [13] (2003), during the study of mass movements in the Bana massif, contributed to the geotechnical characterization of the granites of the massif. Keyangue T. J. H. [15] (2007) has briefly studied the physical properties of sand from the alteration materials of Batié granites (West Cameroon) and made proposals for improving their quality for the manufacture of concrete. Goodwill [16] (2011) did a study on the sand properties of some quarries of Bamenda (especially the sands of Ndop, Woum, Mbattu) with particular interest the equivalent of sand; and made an analysis of their impact in the manufacture of concrete. 


\section{2- MATERIALS AND METHODS}

To better characterize the aggregates of western Cameroon for appropriate use in civil engineering, a suitable methodology must be applied to conduct field work, laboratory and for the calculation of various parameters.

\section{1- Materials}

The main materials are here represented by rocks, soils and aggregates from which we take our different sand samples. For this we used the following equipment and tools:

- A topographic map to position the different sampling sites;

- A Mercedes vehicle (truck) with a load capacity of twenty tonnes for the movement and transport of samples

- Pickaxe, shovel and hoe to dig trenches to collect samples and load them into bags;
- Polystyrene bags used to collect samples;

- A decameter for taking measurements of different variants;

- $\quad$ PPE (Personal Protective Equipment) for personal safety;

- Pens and notepads for taking data on site;

- A camera for shooting

$\checkmark \quad$ Location of the study site

In the locality of West Cameroon, several sand quarries are open. An inventory of these last ones during many descents in the field made it possible to make a choice related to the geotechnical studies of the aggregates coming from these different sites: localization between the parallels $5^{\circ} 25$ 'and $5^{\circ} 28^{\prime} 00^{\prime}$ 'of Latitude North and the meridians $10^{\circ} 20^{\prime}$ 'and $10^{\circ} 25^{\prime} 00^{\prime}$ '.

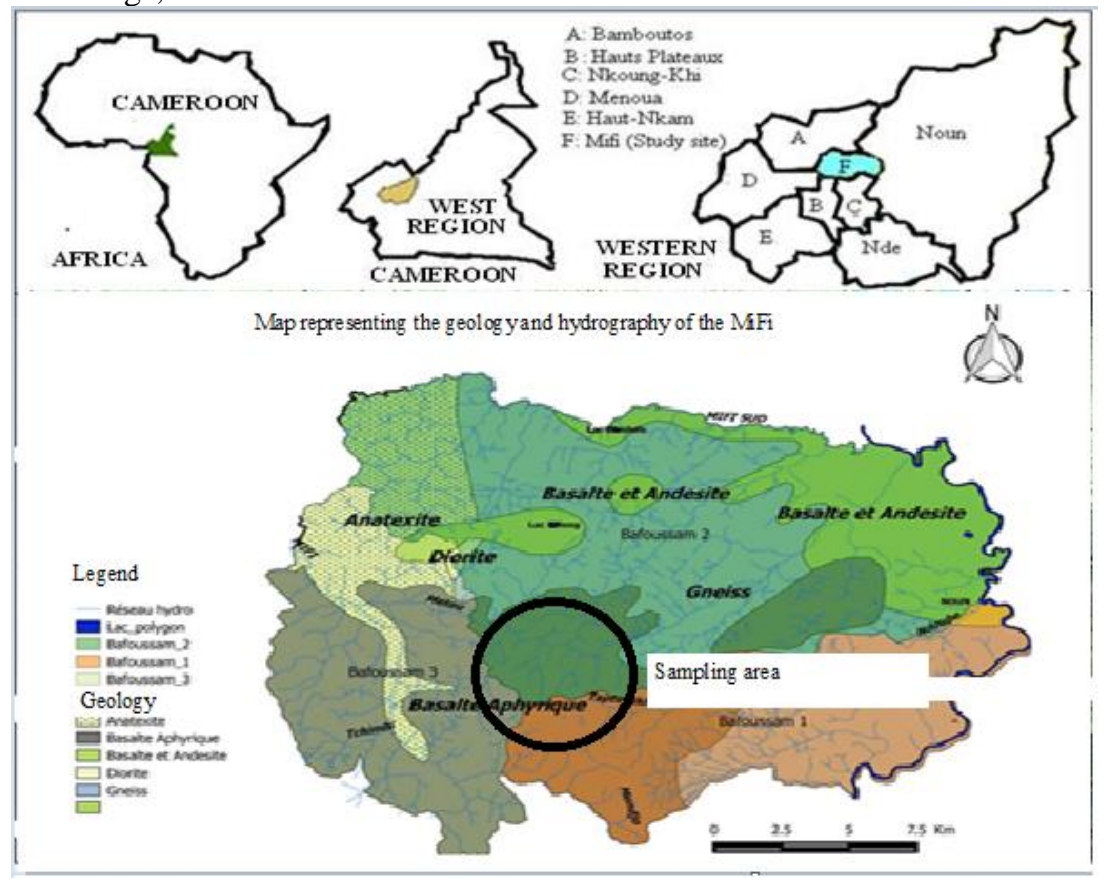

Location of the study area

\section{Sampling}

In order to have the most representative samples, the approach of <shovel in butte> was necessary, it was necessary to mix the materials which one made of a bleeding on the whole height of the face of size. Then, the quarterly sampling method made it possible to determine our operation by retaining the quantities necessary for laboratory work. The reworked samples taken from each sand were packaged in polystyrene bags and labeled. They were used for mechanical identification of each of these sands (CBR, concrete formulation, optimum water content, etc.). Laboratory work was carried out on the various sand samples at the Laboratory of Engineering and Industrial and Environmental Systems (URISIE) of the University Institute of Technology FOTSO Victor Bandjoun associated with the Laboratory of Mechanics and Modeling of Physical Systems (UR2MSP).

\section{2- $\quad$ Experimental methods}

In this part, the experimental methods will be presented for the determination of the different characteristics of the material. Among others:

> Physical characteristics: Water content, density, specific gravity, sand swell, absorption coefficient, degree of surface cleanliness or equivalent of sand, loss of mass.

\section{Water content}

The water content of the materials studied was determined by the method of steaming according to the prescription of standard NF P 94-050 (1995).

$$
W(\%)=\frac{M_{w}}{M_{s}} * 100=\frac{M_{h}-M_{s}}{M_{s}} * 100
$$

With: Mw = Mass of water; Ms = Mass of dry soil and Mh $=$ Mass of wet soil 


\section{Density (apparent density)}

The measurement of the density was carried out according to the standard NF EN 1097 - 6; NT 21-193.

$$
\rho_{\text {app }}=\frac{M_{\text {ech }}}{M_{\text {liq }}} * \rho_{\text {liq }}
$$

With: Mech: Mass of the sample gram (g) and Mliq: Mass of the liquid (water) gram and pliq:

Density of the liquid in $(\mathrm{g} / \mathrm{cm} 3)$

\section{Specific mass (absolute or real density)}

The determination of the specific gravity of the studied materials was carried out with the use of the method of the water pycnometer according to the prescriptions of standard NF P 94-054. The absolute density sought is:

$$
\rho_{s}=\rho_{w} * \frac{M_{2}-M_{1}}{M_{4}+M_{2}-M_{1}-M_{3}}
$$

With $\rho w$ : Density of water taken conventionally equal to 1 $\mathrm{g} / \mathrm{cm} 3$

\section{Measurement of the cleanliness of sands: equivalent of} sand

Sand cleanliness is routinely assessed using the sand equivalent test. It is carried out on the fraction of sand passing by $5 \mathrm{~mm}$ sieve, following the prescriptions of the standards NF EN 933-8 and NT 21 - 26.

The value of the equivalent of the desired sand is obtained using the expression:

$$
E S=\frac{E S_{V}+E S_{P}}{2}
$$

Where ESV and ESP are respectively the equivalent of visual sand and the equivalent of sand measured at the piston

\section{Sand blasting}

The abundance of materials has been studied on the basis of the principle described by standard NFP 18-558. This test consists of the fineness module and the state of the material (water content) through the abacus to determine the expansion coefficient

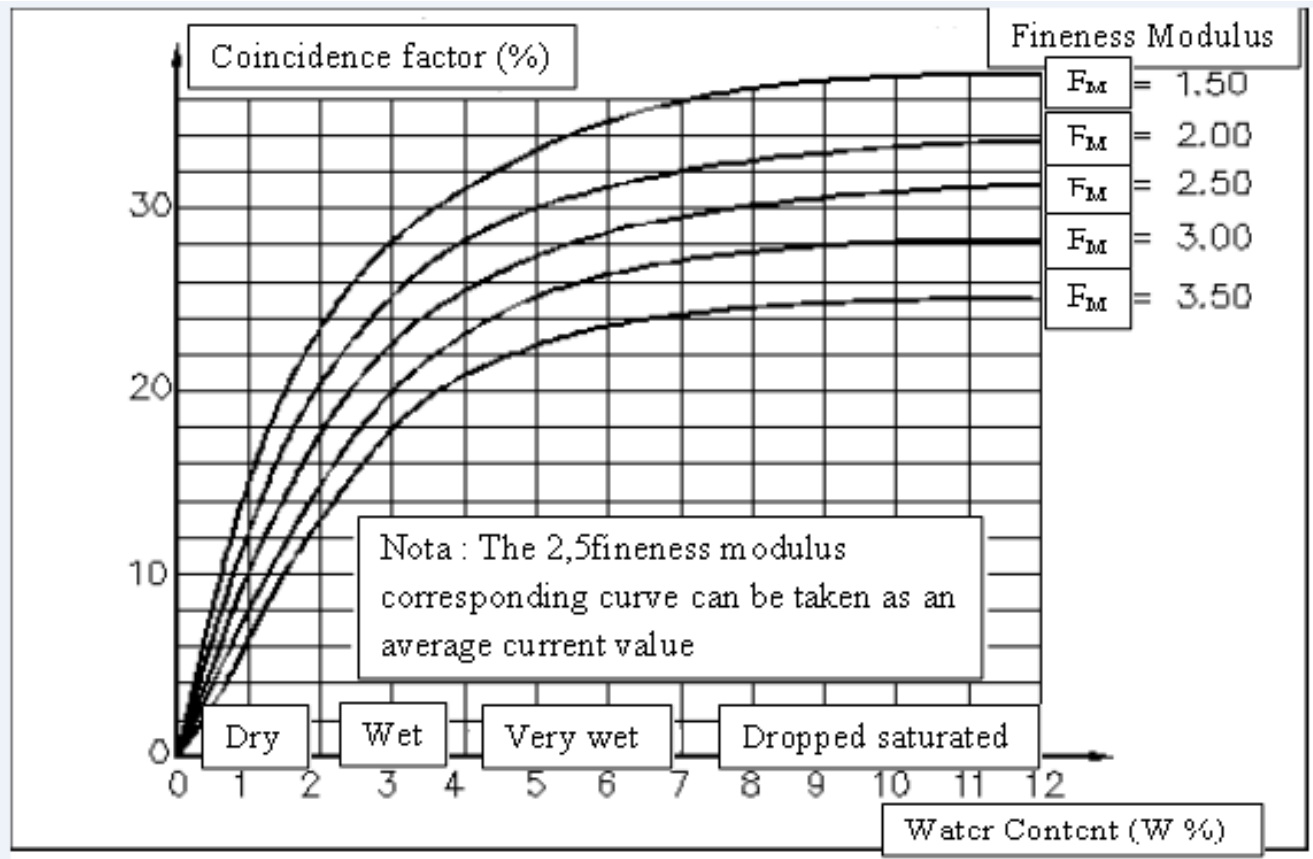

Determination of the expansion coefficient

\section{Absorption coefficient}

The absorption coefficient of the materials studied was evaluated by the method described in standard NT 21-193; EN 1097 - 6.

The water absorption coefficient (in \%) of the sand was determined by the formula:

$$
A_{b}=\frac{M_{h}-M_{s}}{M_{s}} * 100
$$

With: Mh the final dry mass and MS the initial dry mass of the sample under test.

\section{Mass loss control test (NF P 20-049)}

The loss of mass of the materials was studied on the basis of the principle and the procedure described by the standard NFP20-049. The latter states that the weight loss coefficient is defined by:

$$
C_{p}=\frac{M_{0}-M_{f}}{M_{0}} * 100
$$

With: M0 is the initial mass of the sample and Mf is the final mass after execution of the test.

$>$ Geometric characteristics: The granular composition, the fineness modulus, and the flattening coefficient

Sieve analysis by dry sieving (NF P 94-056)

Particle size analysis of the various materials was carried out by the dry route. It makes it possible to determine the size and the respective weight percentages of different families of grains constituting the soils.

The fineness module, quantifying the more or less fine character of the sands corresponds to the sum of the percentages of the accumulated refusals brought back to the unit for the sieve of the modules $23,26,29,32,35$, and 38 . It is given by the following expression: 
$M_{f}$

$=\frac{\left(\% R_{5}+\% R_{2,5}+\% R_{1,25}+\% R_{0,63}+\% R_{0,315}+\% R_{0,160}\right)}{100}$

Where \% $\mathrm{Ri}$ is the percentage of the cumulative rejection on the separate sieve on the opening sieve $\mathrm{i}$ (in $\mathrm{mm}$ ).

It is important to note that when the material passing through the $63 \mathrm{~mm}$ sieve has more than 50\% refusal of $0.080 \mathrm{~mm}$, the uniformity $(\mathrm{Cu})$ and curvature $(\mathrm{Cc})$ coefficients can be calculated using the expressions following:

$$
\begin{gathered}
C_{u}=\frac{d_{60}}{d_{10}} \\
C_{c}=\frac{d_{30}^{2}}{d_{10} \times d_{60}}
\end{gathered}
$$

Or dy: dimension of the sieve corresponding to $y \%$ of passing.

\section{Particle size analysis by sedimentation (NF P 94-057)}

The objective of the test is to determine the particle weight distribution of a soil with the largest dimension equal to 80 $\mu \mathrm{m}$ and the smallest larger than $1 \mu \mathrm{m}$. This test completes the sieving analysis.

Stokes law: $V=\frac{\left(\gamma_{s}-\gamma_{w}\right) \cdot g \cdot D^{2}}{18 \eta} \quad$ with $\eta \quad$ the viscosity of the liquid

> Mechanical characteristics: CBR, concrete formulation, optimal water content, optimal density.

\section{Proctor Trial}

The Proctor Normal or Modified test is used to find the optimum water content that leads to the best compaction of the material. The compaction of a sample of material is done in a standardized mold, using a standardized lady, according to a process defined by NFP 94-093.

\section{CBR test}

The Californian Bearing Ratio (CBR) is a load bearing test (ability of materials to withstand the loads) of embankments and compacted layers of road structures. It consists in experimentally determining the bearing indices (IPI, CBR). According to NF P94-078 standard.

\section{Formulation of concretes}

The purpose of concrete formulation is to determine, according to the handling and resistance criteria defined by the specifications, the nature and the quantities of materials necessary for the manufacture of a cubic meter of concrete. is to define, according to the type of work to be done, the parameters necessary for the implementation of the concrete and the short and long term stability of the structure

\section{3- RESULTS AND DISCUSSION}

\section{1- RESULTS}

At the end of this study, it appears that the values of the physico-mechanical parameters of the MiFi quarry sands in the MiFi catchment area in the Western Region were specifically obtained and presented in the following tables and figures:

\begin{tabular}{|l|l|l|l|l|l|l|}
\hline \multicolumn{9}{|c|}{ Sample } & Source & Water & Volume Mass g / $\mathrm{cm}^{3}$ & \multicolumn{2}{l|}{ Sand Equivalent $\%$} \\
\cline { 4 - 7 } & & Content $\%$ & Apparent & Absolute & Visual & Piston \\
\hline Sand & Quarry & 10.84 & 1.9 & 2.46 & 70.8 & 63.6 \\
\hline
\end{tabular}

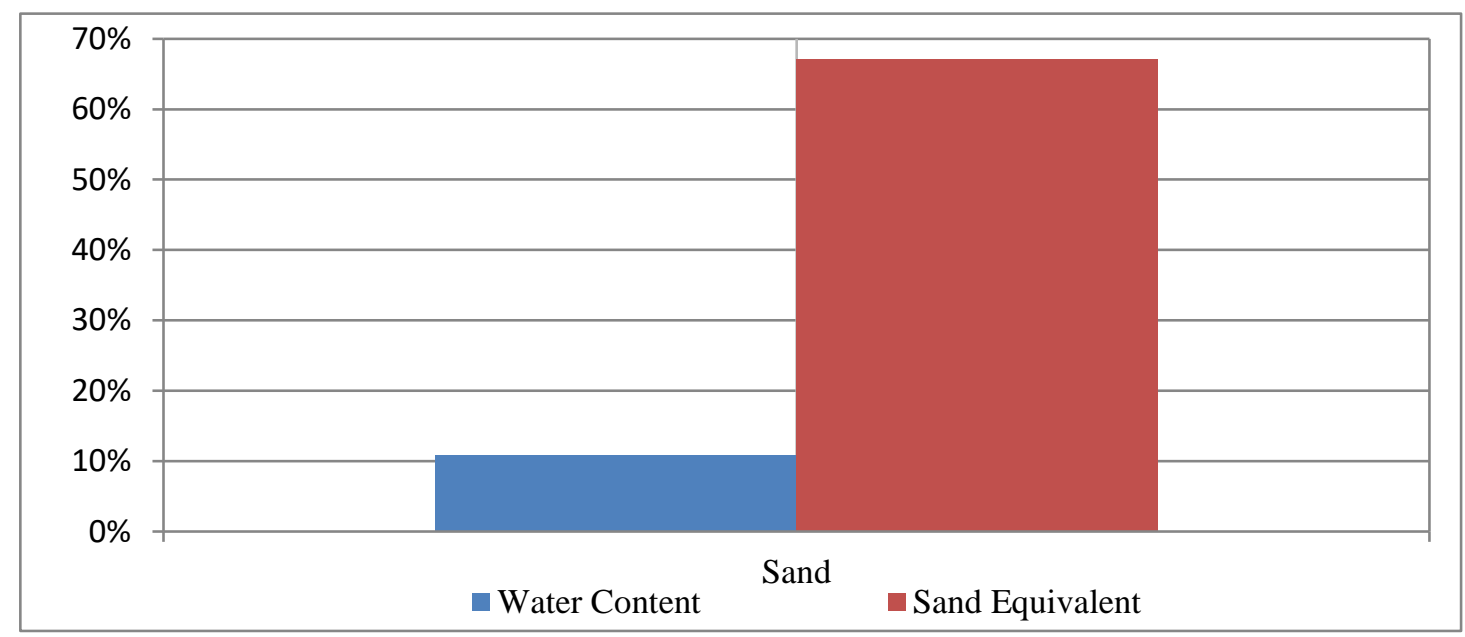

Water content and sand equivalent histogram 


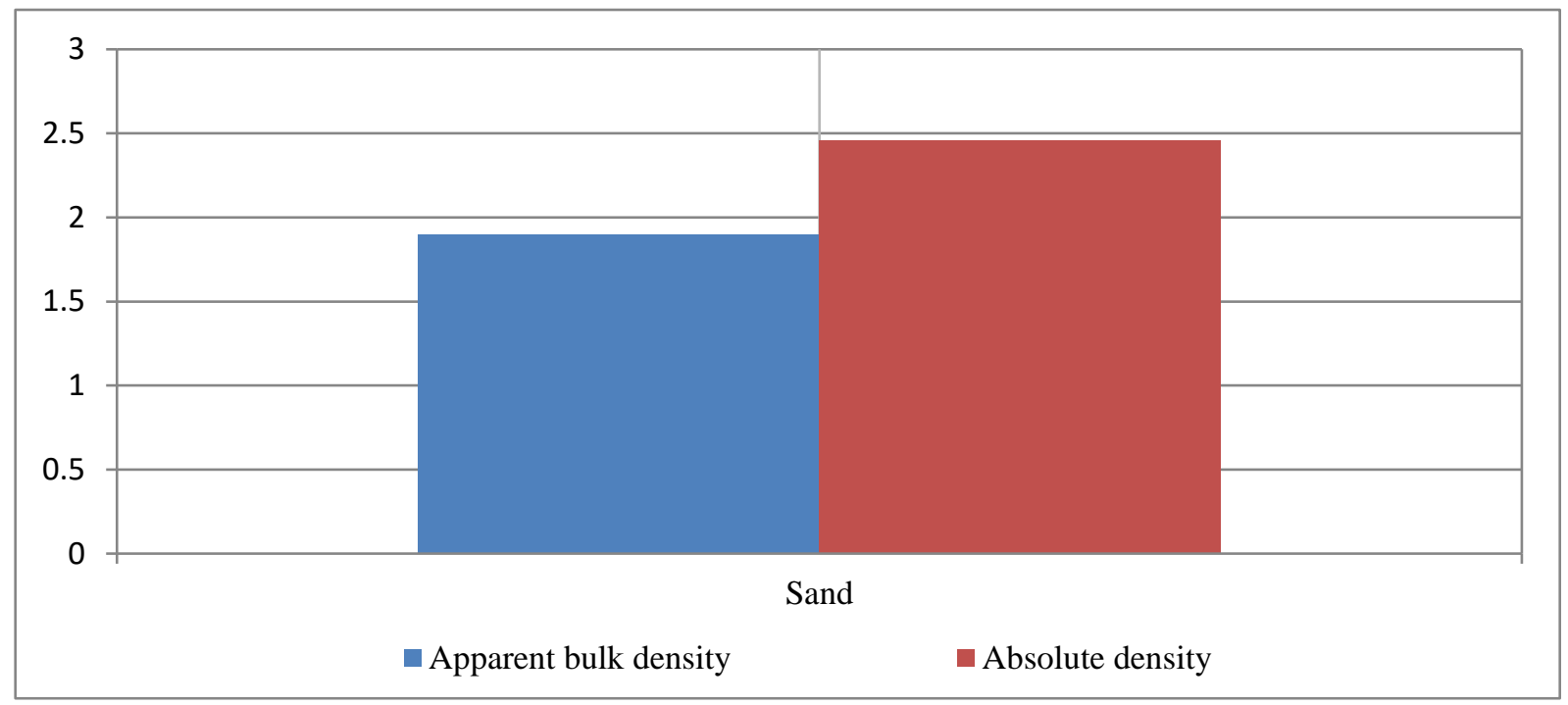

Apparent bulk density and absolute density histogram

Sand analysis parameters

\begin{tabular}{|l|l|l|l|l|l|l|l|}
\hline Sample & Source & Parameters & \multicolumn{5}{|l|}{} \\
\cline { 3 - 8 } & & $\begin{array}{l}\text { Fineness } \\
\text { modulus } \mathrm{M}_{\mathrm{f}}\end{array}$ & $\begin{array}{l}\text { Coefficient of } \\
\text { curvature } \mathrm{C}_{\mathrm{c}}\end{array}$ & $\begin{array}{l}\text { Coefficient of } \\
\text { uniformity } \mathrm{C}_{\mathrm{u}}\end{array}$ & $\begin{array}{l}\text { Fine content } \\
(\%)\end{array}$ & $\begin{array}{l}\text { Sand } \\
\text { content }(\%)\end{array}$ & $\begin{array}{l}\text { Grit content } \\
(\%)\end{array}$ \\
\hline Sand & Quarry & 3.3 & 1.1 & 5.36 & 16 & 56 & 28 \\
\hline
\end{tabular}

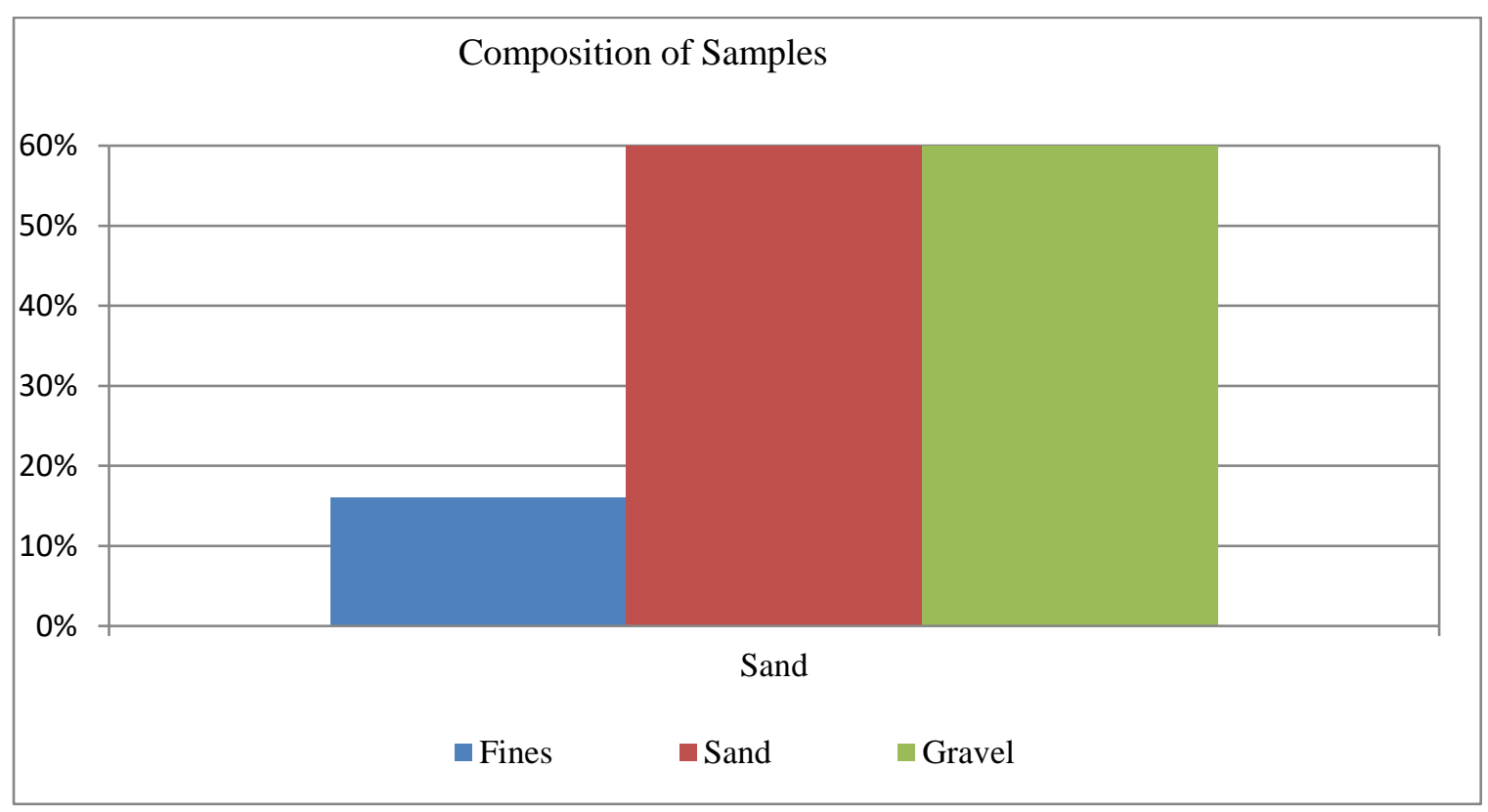




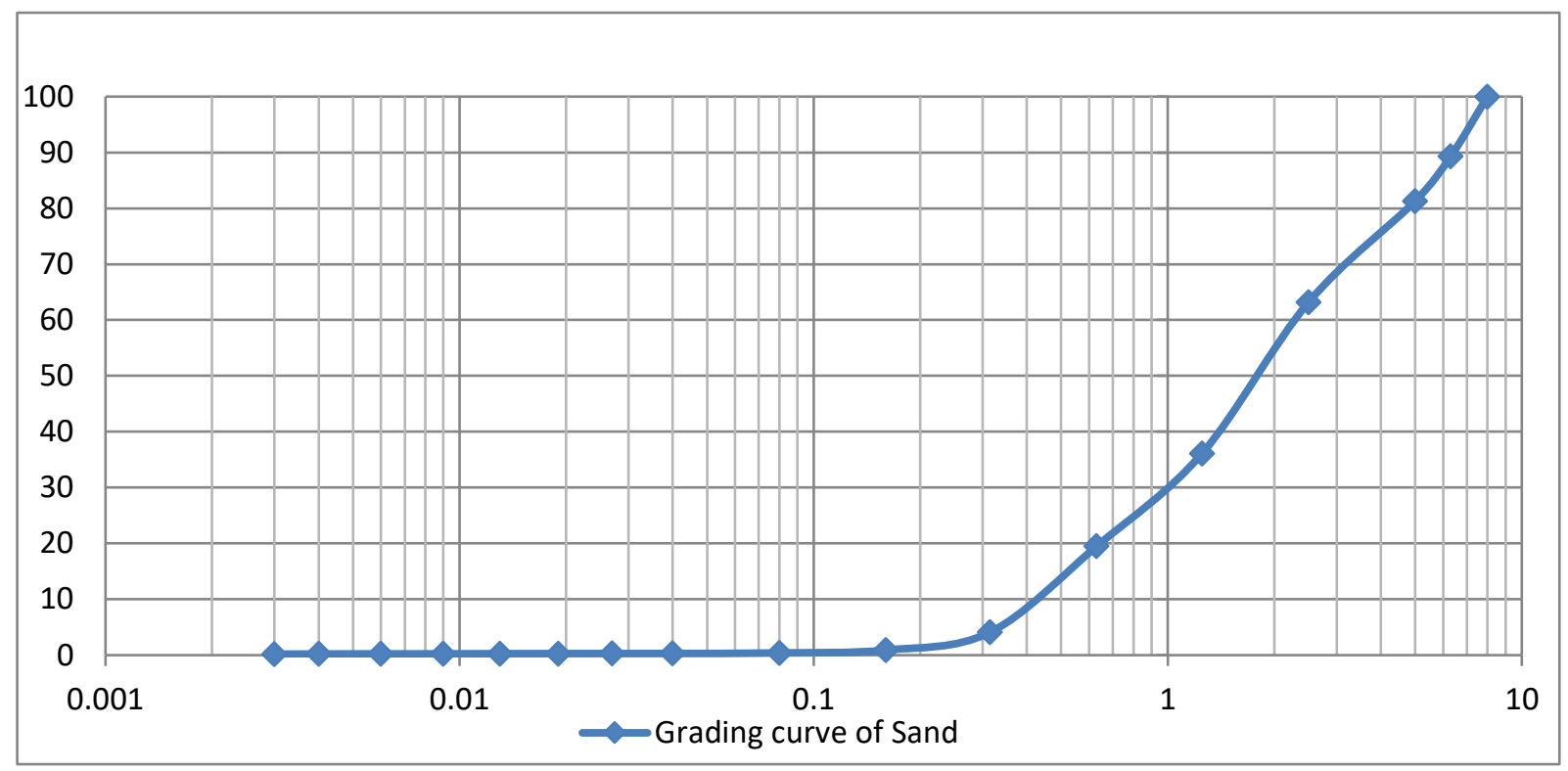

Mechanical parameters

\begin{tabular}{|l|l|l|l|l|l|c|}
\hline \multirow{3}{*}{ Sample } & Provenance & \multicolumn{2}{|c|}{ Proctor Test Normal } & \multicolumn{2}{c|}{ Proctor Test Change } & CBR Imedia Trial \\
\cline { 3 - 6 } & & $\begin{array}{c}\text { Optimal Water } \\
\text { Content } \%\end{array}$ & $\begin{array}{c}\text { Maximum Dry } \\
\text { Density }\end{array}$ & $\begin{array}{c}\text { Optimal Water } \\
\text { Content } \%\end{array}$ & $\begin{array}{c}\text { Maximum Dry } \\
\text { Density }\end{array}$ & \multirow{2}{*}{10.37} \\
\hline Sand & Quarry & 12.18 & 1.68 & 14.8 & 1.74 & \\
\hline
\end{tabular}
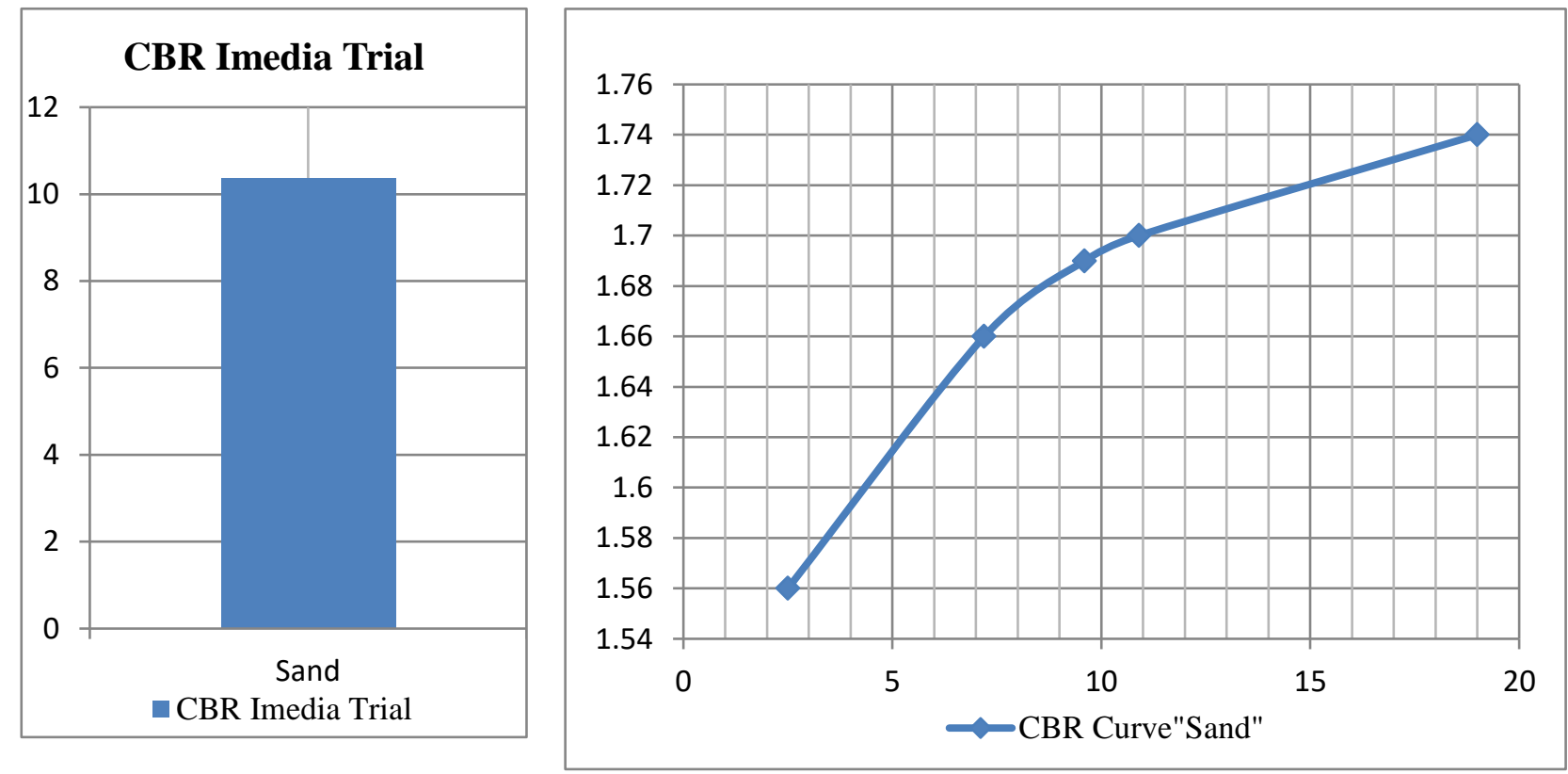

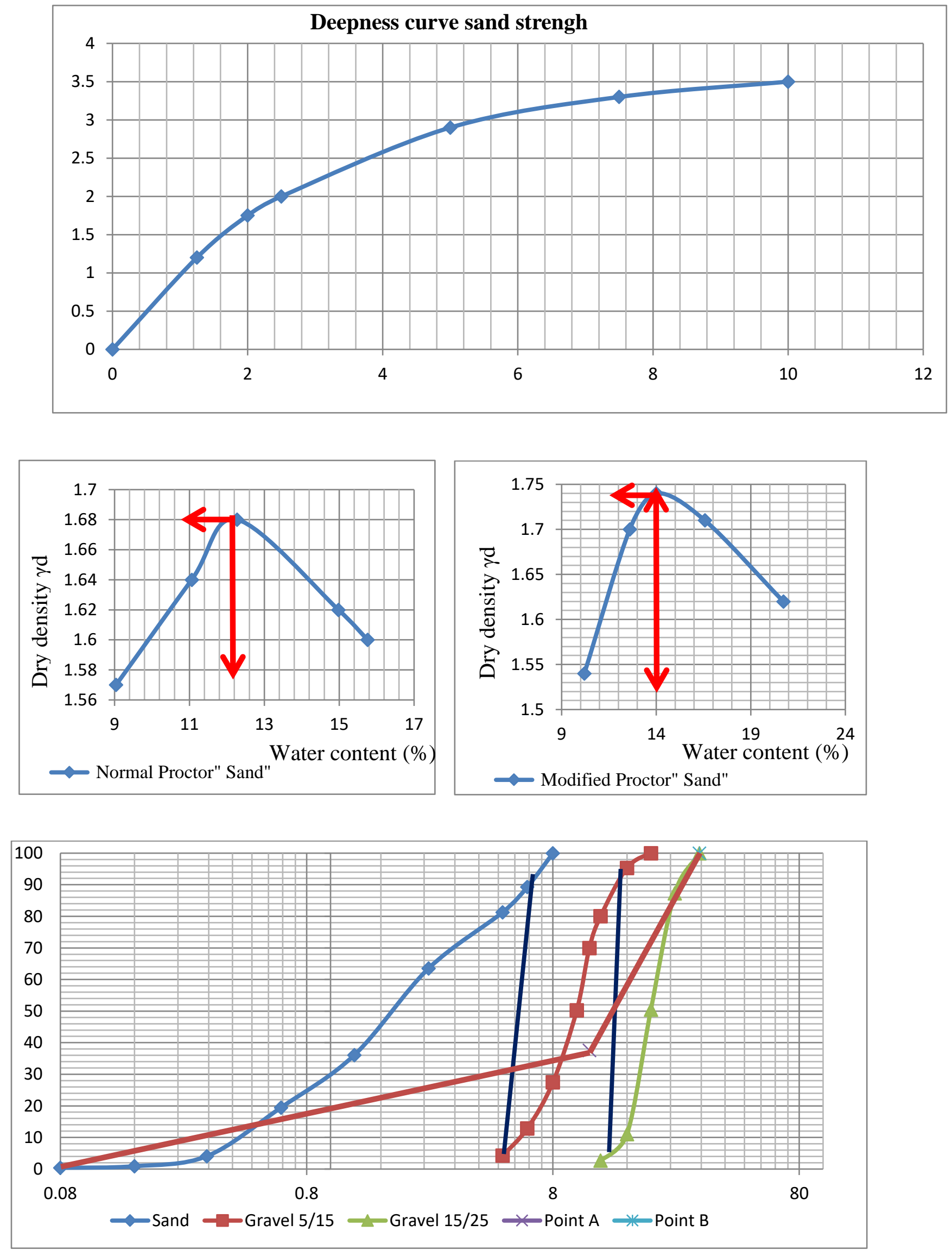

Grading curves of "Sand" and the various Gravels 


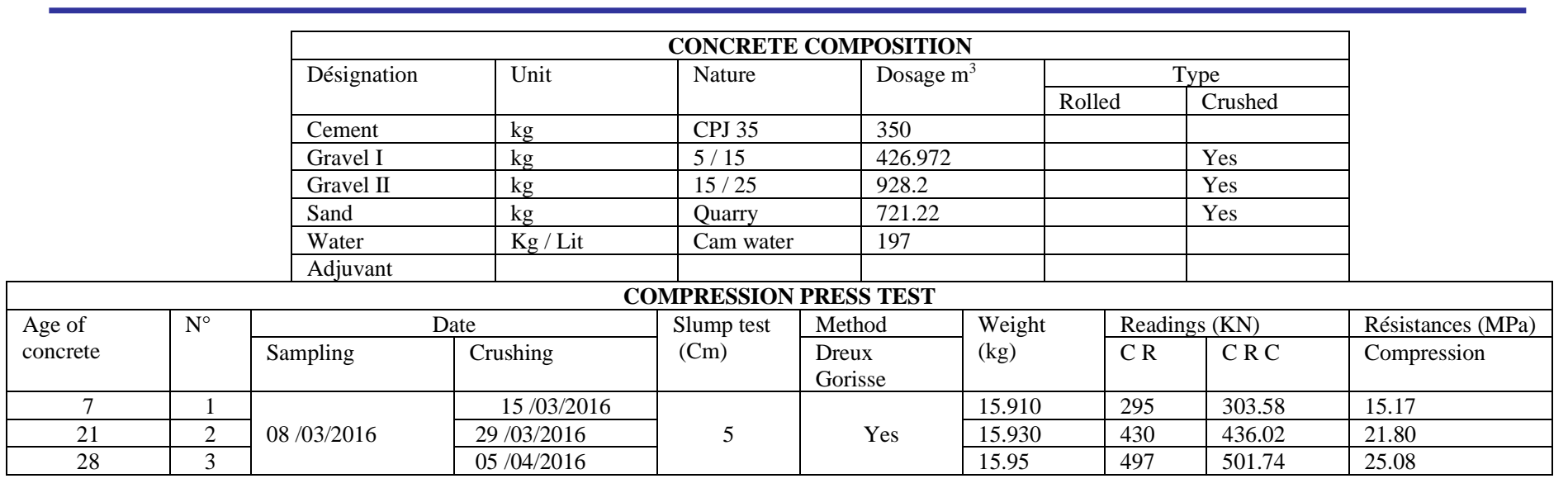

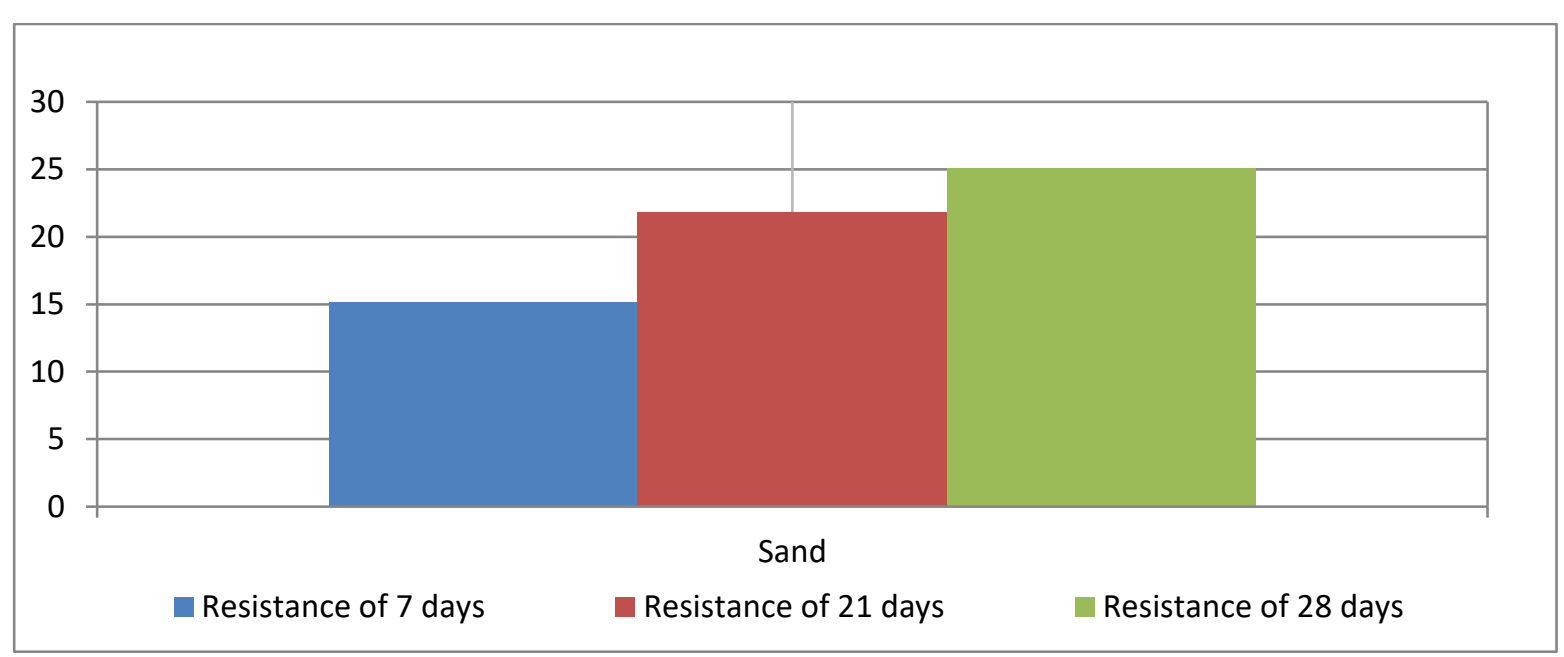

Concrete resistances histogram at different days

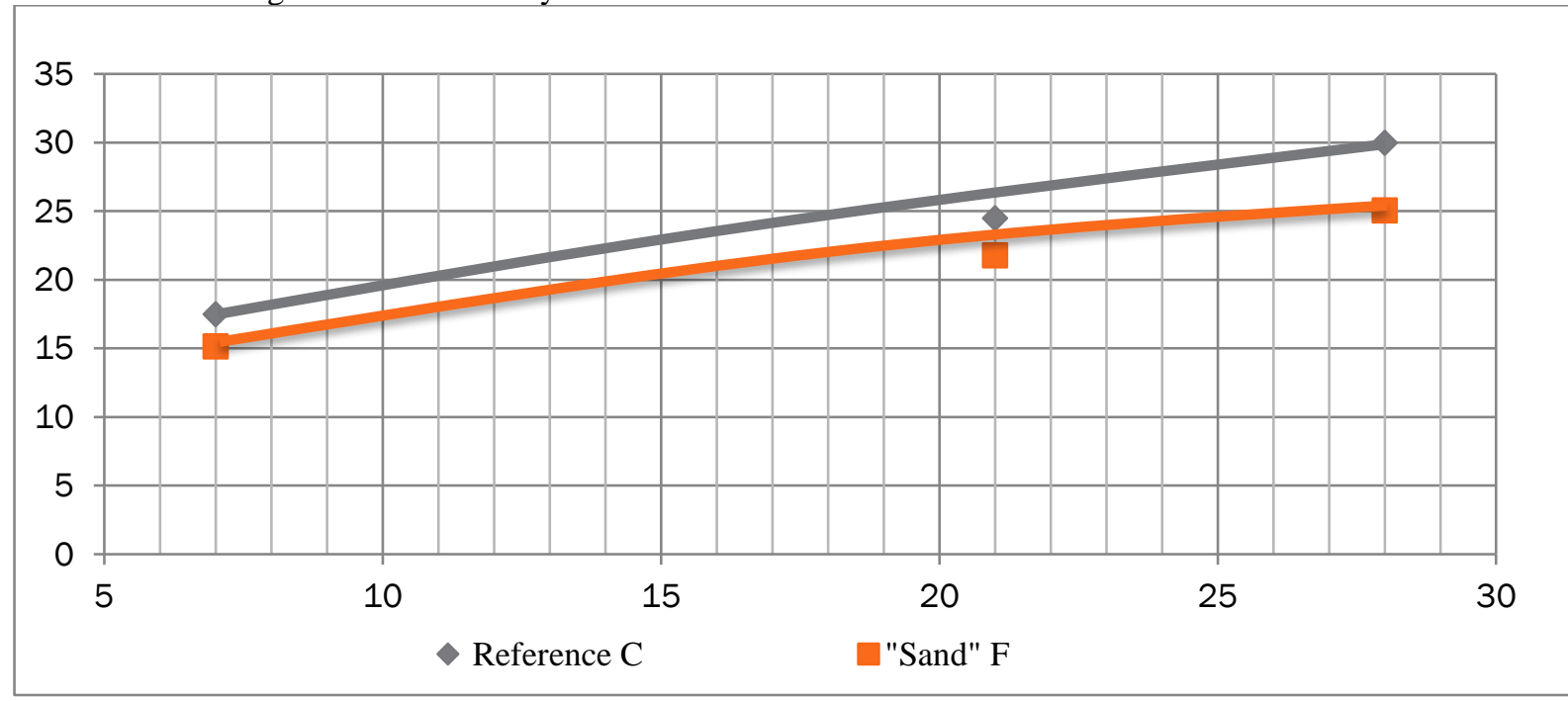

Curves of resistance of the test-tubes (various compositions) to different days

\section{2 - DISCUSSION}

After performing the various tests in the laboratory, it follows:

$>$ The sand has a water content of 10.8 which results in a low content of fine particles, which makes it possible to affirm that this soil is in a compact or dense state and therefore has a lower vacuum index.
$>$ The apparent density of the sand is greater than $1.4 \mathrm{~g} / \mathrm{cm} 3$ which confirms that the studied material is a granulate and its specific mass varies from $2 \mathrm{~g} / \mathrm{cm} 3$ to $3 \mathrm{~g} / \mathrm{cm} 3$ which means that we are in presence of a common granulate.

$>$ The sand equivalent of sand has a sand equivalent value of between $60 \%$ and $70 \%$, therefore, it is recommended for the realization of a concrete of standard quality which can present a slightly 
strong withdrawal. The cement used must necessarily be Portland type.

$>$ The dry density at sand OPM varies from $1.53 \mathrm{t} /$ $\mathrm{m} 3$ to $1.74 \mathrm{t} / \mathrm{m} 3$, its water content at OPM is $14.8 \%$ and this shows that the material is recommendable for the preparation of the base layers of pavements.

$>$ Sand with a CBR Index between 8 and 12 which leads to a soil class $\mathrm{S} 2$.

$>$ After plotting the grain size curve and various calculations, the sand has a curvature coefficient $\mathrm{Cc}<1$ and the coefficient of uniformity $\mathrm{Cu}<4$ this indicates that we are in the presence of a badly graduated gravity. Furthermore, According to the value of its fineness module, which is 3.3 , the sand is qualified as coarse.

$>\mathrm{We}$ can therefore conclude that concrete formulated with sand is a quality concrete, the resistance obtained is equal to the desired resistance. Therefore are common concretes.

\section{4 - CONCLUSION AND PESPECTIVES}

\section{CONCLUSION}

At the end of our study, we were talking about performing a Physico-Mechanical Characterization of the MiFi Career Sands in the MiFi River Basin for use in Civil Engineering. For this reason, we have this characterization of the physico-mechanical parameters that have been presented and interpreted. From this results the physical and mechanical properties of the material taken from the site. In the end, the results obtained during this study lay the foundations of a Physico-Mechanical Database of the Care Sands of the MiFi in the Western Region of Cameroon.

\section{PROSPECTS}

- For the cement field, it is necessary to make a quantitative and qualitative mineralogical study, because the resistances depend on it.

- For the field of mechanical tests on hardened concrete, the tests (compression and tensile splitting) must be made. Non-destructive testing must also be done with sclerometrics.

- The effects of dimensional variations have not been taken into account for modeling swelling and shrinkage. It would be of paramount importance to study them because of them depend the complex phenomena of setting and the hardening of mortars and concretes.

- For the study of Pathologies, it is necessary to make a study to complete the detailed visual inspection of the Structures, to assess the quality of the materials in place and to characterize the current mode of operation of the structure.

\section{BIBLIOGRAPHIC REFERENCES}

[1] F.MICHEL, 1974.Some notions of geology .CTMNC, P.9

[2] YANG WENJIN, 1993. Geochemistry and mineralogy of granites from the Helai region, Guangdong province, southern China. These Sci., Univ. Quebec to Chicoutimi, 288p.
Laboratory of Civil Engineering and Mechanical Engineering, INSA Rennes, 1-11

[3] GERAULD Y. and AL., "Comparison between connected and overall porosity of thermally stressed granites", Journal of Structural Geology, Vol. No.8 / 9, 1992, pp.981-990.

[4] BRACE W.F., $<<$ brittle bill of rocks. In: state of stress in the Earth's crust $\gg$, Proceedings of the International Conference, Santa Monica, NEW YORK, 1964, AMERICAN ELSEVIER Publishing Co., p.110-178

[5] EBERRHADT E., Stead D., StimpsonB., Read R.S., << Identifying crack initiation and propagation thresholds in brittle rock $\gg$ Canadian geotechnical journal. Vol.35, No.2, 1998, p. 222-233

[6] LACROIX, 1993. Laterites of Guinea and the products of alteration associated with them. N. Arch. Mus. Hist. Natur., P. 255-358.

[7] ARSANDAUX (H.). , 1931 Contribution to the study of altered silicate aluminous rocks in intertropical regions. Bull. Soc. Fr. Min., T. XXXVI, p. 70-110.

[8] ERHART (H.), 1956. The genesis of soils as a phenomenal geological. PARIS, Edit. MASSON, 90 pages.

[9] MAIGRIEN, 1958. Contribution to the study of soil encroachment in French guinea. Thesis, University of STRASBOURG. Roneotype document, 311p.

[10] LENEUF (N.), 1956. Alteration of calco-alkaline granites and granodiorites in ivory coast festiere and soils derived therefrom. Unpublished report, ORSTTOM, 37pages.

[11] VAN DER MERVE, 1955. The Clay Materials of Subtropical Soil Groups of the Union of South Africa. African Sals, vol IV, no. 2, p. 106 .

[12] YONGEUFOUATEU R., 1986. Contribution to the petro logical study of the alteration and facies ferruginous cuirassement of migmatitic gneisses of the Yaoundé region. 3rd cycle thesis, Univ. Yaoundé, 214p.

[13] KOUAYEPLEWOU S., 1987.-Supergenic alteration of grenadier rocks of the bana region (CAMEROON): petrologymineralogy. Thesis doct. 3rd cycle, Univ. Poitiers, 170p.

[14] NGANDJANG J. G. A., 2003 - Alterations in the tropical zone. Meaning through old and / or current mechanisms. C.R. Geosciences, 335, pp. 1109-1119.

[15] KEYANGUETCHOUATA J., 2007. Physical characterization of sands from alteration materials of building granites and improvement of quality for concrete construction. Master's degree, Fac. SCI. Univ. DSCHANG, 68P.

[16] GOODWILL, 2011. Effect of sand equivalent on concrete strength. Brief to obtain the DIPET II. 99P.

[17] G.-EEKODECK and YVON, 2007. - The alteration of metamorphic rocks of South Cameroon and its geotechnical aspects. Thesis SCI, Univ. Grenoble I: 392 p.

[18] Nguetnkamj.p, 1994. Petro logical study of a granite formation in a tropical forest environment South Cameroon (Central Africa): Demonstration of its polyphase character. Fac. SCI Univ. NGaoundere, 89p.

[19] ARSANDAUX (H.). 1931. Contribution to the study of aluminous silicate rocks in intertropical zones. Bull. Soc. Fr. Min., T XXXVI, p. 70-110.

[20] MOYE D., 1955.Engineering geology for the snowy mountains scheme.Journal of the Institution of Engineers Australia, 27, 281-299.

[21] RUXTON B.P. and BERRY L., 1957. Weathering of granite and associated erosional features in HONG KONG. Bulletin of the Geological Society of America, 68, 1263-1292.

[22] G.S.E.G., 1995. GEOLOGICAL SOCIETY ENGINEERING WORKING PARTY: The description and classification of weather rocks for engineering purposes. Quarterly Journal of Engineering Geology, 28 (3), 207-242.

[23] FOOKES P.G., GOURLEY C. S. and OHIKERE C. 1988 Rock weathering in engineering time, Quarterly Journal of Engineering Geology, 21 (1), 33-58

[24] DEARMAN W. R., 1976. WEATHERING classification in the characterization of rock.Bulletin of the international association of engineering geology, 13, 123-127.

[25] IRFAN T. Y. and DEAMAN W. R., 1978. Engineering classification and index properties of a weathered granite. 
Bulletin of the International Association of Engineering Geology, 17, 79-90.

[26] IRSM (International Society of Rock Mechanics). 1981 Basic geotechnical description of rock masses: International journal of rock Mechanics and Mining Science and Aeromechanics Abstracts, 22, 51-60.

[27] LEE S.G. and FREITAS M.H., 1989. Revision of the description and classification of granular weathering and its application to granites in Korea.Quarterly journal of engineering geology, 22, 31-4.

[28] Fetgo B. (2002) Geotechnical characterization of alteration products on rhyolitic tuffs of the Bafou sector.

[29] LETOUZEY, R., 1969. Explanatory note of the phytogeographic map of Cameroon at 1/50000. International Institute of Vegetation. Toulouse, France Fac, Sc. 3 and 4. Pp50-52

[30] FEUGUENG, J., 2001. Annual activity report of the agricultural post of Bâtie. Fiscal year 2000/2001. 70p.

[31] NZENTI et AL., 1984. A new example of a granulitic belt in a protozoan collision chain: the migmatic from Yaoundé in Cameroon. C.R.Acad. SCI. Paris, 299 ,

[32] French Standard, 1995. Geotechnical Volume I \& ET 2. Edit. AFNOR, Paris.

[33] Jean FESTA, Georges DREUX, 2006. New guide to concrete and these constituents, 8th edition. Edit. Eyrolle Group, Paris, 403p.

[34] CEREPTP (experimental center for research and studies of building and public works), 1984. Practical guide for pavement design for tropical countries. Edit. French Documentation, Paris, $155 \mathrm{p}$

[35] Revue Française de Geotechnique, 1983. Geotechnical and soil surveys and materials. Draft DTU, RFG, No22, February 1983, Edit. Crushed Presses, 27 pages.

[36] LABOGENIE, 1983. Recommendation for the use of pavement foundations in crushed gravels, 27 pages.

[37] NF P 20-049-2,1996. Soils: recognition and testing Determination of the water content of materials - Part 2: hot plate or radiant panels method.

[38] NF P 94-078. Soils: recognition and testing- CBR after immersion - Immediate CBR index-Immediate index.

[39] NF P 94-093. Soils: recognition and testing- Proctor normal tests- Modified proctor tests.

[40] NF P94-050, 1995. Soils: Recognition and Testing Determination of the water content of the materials. Method of stoving.

[41] NF EN 1097-6, 2014. Tests to determine the mechanical and physical characteristics of aggregates.

[42] NF P 94-054, 1991. Soils: recognition and testing Determination of the density of solid particles in soils - Water pycnometer method.

[43] NF EN 933-8, 2012. Tests to determine the characteristics of aggregates- Part 8: evaluation of fines - Sand equivalent

[44] NF P 18-558. Absolute density of fines.

[45] NF P 94-056, 1996. Soils: recognition and testing - Particle size analysis - Dry sieve method after stirring.

[46] NF P 94-057, 1992. Soils: recognition and testing - Particle size analysis - Sedimentation method. 